\title{
Translocation of trapped Bolivian river dolphins (Inia boliviensis)
}

\author{
EnZo Aliaga-RosseL ${ }^{1,3}$ AND Mariana Escobar-Ww ${ }^{2}$
}

Contacte-mail: ealiagar@hotmail.com

\begin{abstract}
The Bolivian river dolphin, locally known as the bufeo, is the only cetacean in land-locked Bolivia. Knowledge about its conservation status and vulnerability to anthropogenic actions is extremely deficient. We report on the rescue and translocation of 26 Bolivian river dolphins trapped in a shrinking segment of the Pailas River, Santa Cruz, Bolivia. Several institutions, authorities and volunteers collaborated to translocate the dolphins, which included calves, juveniles, and pregnant females. The dolphins were successfully released into the Río Grande. Each dolphin was accompanied by biologists who assured their welfare. No detectable injuries occurred and none of the dolphins died during this process. If habitat degradation continues, it is likely that events in which river dolphins become trapped in South America may happen more frequently in the future.
\end{abstract}

KEYWORDS: BOLIVIAN RIVER DOLPHIN; HABITAT DEGRADATION; CONSERVATION; STRANDINGS; TRANSLOCATION; SOUTH AMERICA

\section{INTRODUCTION}

Small cetaceans are facing several threats from direct or indirect human impacts (Reeves et al., 2000). The pressure on South American and Asian river dolphins is increasing; evidently, different river systems have very different problems. Habitat degradation, dam construction, modification of river channels, incidental mortality in fisheries, river pollution, boat traffic, and other threats jeopardise their survival (Aliaga-Rossel, 2010; Choudhury et al., 2012; Kelkar et al., 2010; Reeves et al., 2000). The negative effects of these threats, often combined, can occur in remote areas where they are difficult to monitor.

Uncontrolled agricultural frontier expansion, development plans in rural areas, and overfishing are related to the dramatic decline in river dolphin populations in the densely populated regions of southern Asia. Habitat degradation eventually led to the extinction of the Baiji (Lipotes vexillifer) in China (Reeves and Gales, 2006; Smith et al., 2008; Turvey et al., 2007) and is threating the survival of the Ganges river dolphin (Platanista gangetica) in India (Wakid and Braulik, 2009). Irrawaddy dolphins (Orcaella brevirostris) in the Mahakham River in Indonesia may be facing the impacts of agricultural activities; with only 85 individuals remaining from this once common species in the heavily dammed Lower Mekong basin (Reeves et al., 2000). In South America there is little information on the effects of habitat degradation on river dolphins, however, megaprojects such as dams, roads and agricultural expansion are described as threats for these species (Trujillo et al., 2010; Trujillo et al., 2011).

The Bolivian river dolphin (Inia boliviensis), locally known as bufeo, is an endemic species of the upper Madeira basin (Aliaga-Rossel, 2010) distributed in the Mamore, Itenez and Abuna sub-basins in Bolivia. Molecular and morphometric studies indicate that the bufeo has the lowest genetic variability among all river dolphins and represents a distinct species, geographically isolated from the boto or Amazon River dolphin (I. geoffrensis) (Gravena et al., 2014; Ruiz-Garcia et al., 2008). This species has been categorised by the Red Book of Wildlife Vertebrates of Bolivia as Vulnerable (VU), highlighting the need to conserve and protect them from existing threats (Aguirre et al., 2009). This VU categorisation is equivalent to that of the International Union for Conservation of Nature (IUCN) Red List. However, despite this, few actions have been proposed to improve the conservation status of this threatened species. The IUCN has recently listed Inia species as Endangered under the Red List assessment (da Silva et al., 2018), increasing the importance of any conservation action to protect the species.

IUCN (2012), defined 'conservation translocation' as the deliberate movement of organisms from one site for release in another, when the primary objective has a conservation benefit. These are high profile events that may bring the opportunity to raise awareness of these river dolphin species and of the importance of protecting their habitat. This study describes the activities involved during the rescue and translocation of Bolivian river dolphins trapped in a segment of a tributary river and also presents evidence of how terrestrial habitat alterations affect river dolphin populations.

\section{The Pailas River blockage}

In May 2010 (early dry season), authorities of the Department of Santa Cruz, Bolivia, received information about river dolphins trapped in the Pailas River, a small tributary of the Río Grande. According to the authorities, at the end of April (end of high-water season) the unusually strong current of the Río Grande rapidly changed its course, dragging sediment and sand, which accumulated against an embankment built to protect crops from possible floods. This caused an immediate blockage in the mouth of the tributary, isolating the Pailas River. The blockage consisted of a $3 \mathrm{~m}$

\footnotetext{
${ }^{1}$ University of Hawaii, EECB Program, Hawaii, USA.

${ }^{2}$ Museo de Historia Natural Noel Kempff Mercado (MHNNKM), Santa Cruz-Bolivia.

${ }^{3}$ Current address: Research Associate, Institute of Ecology - Universidad Mayor de San Andrés, Campus Universitario n/n, 27 Street, Cota Cota, La Paz Bolivia.
} 


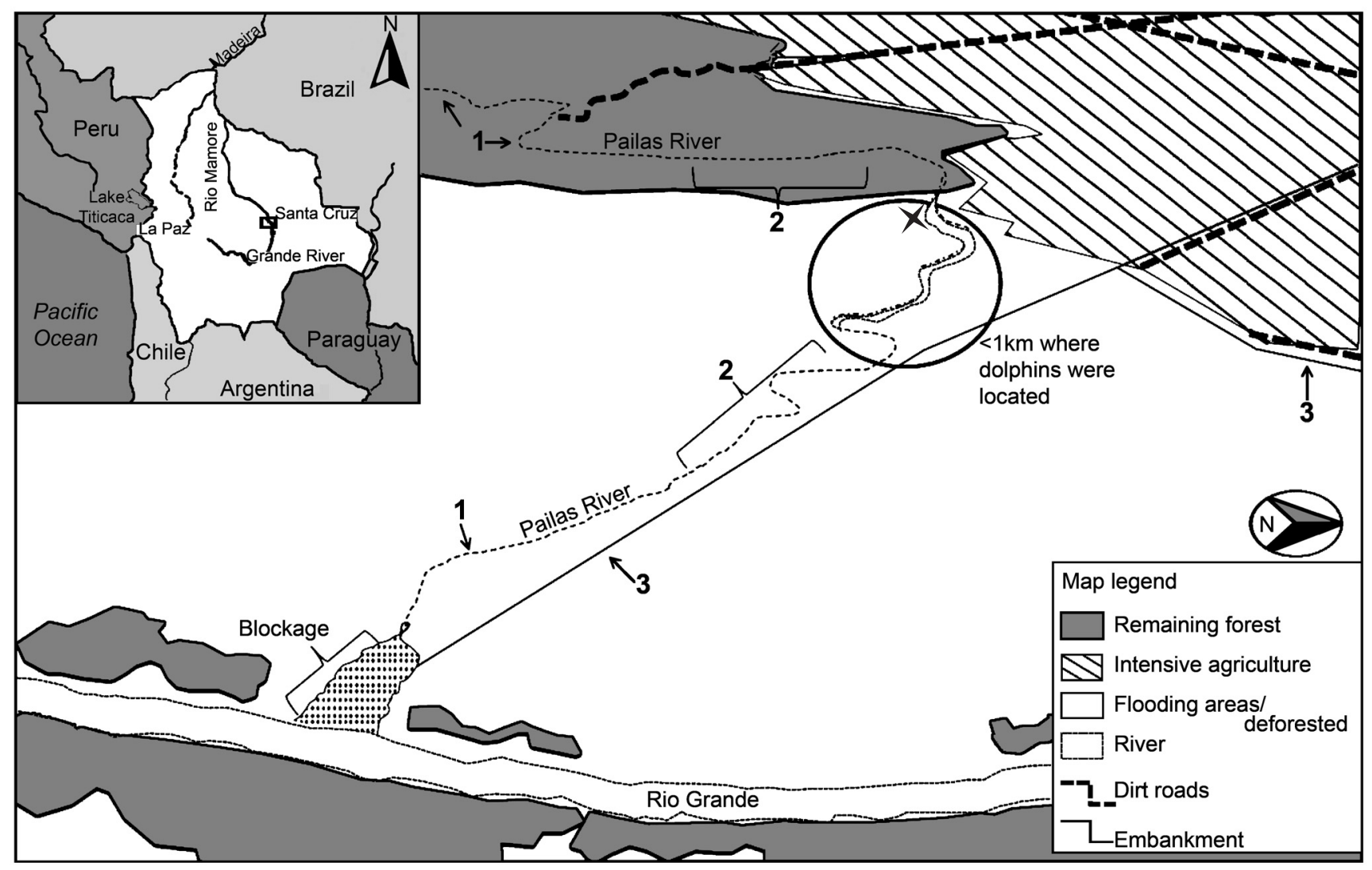

Fig. 1. Location where river dolphins were trapped, figure based on aerial photographs. Pailas River, Rio Grande = Grande River, Santa Cruz- Bolivia. $1=$ Pailas River areas with water levels from 20 to $50 \mathrm{~cm} ; 2=$ water levels of $\leq 1$ meter. $3=$ Embankment. Black cross indicates Hermanos ranch.

high pile of sand and sediments extending 500m from the Río Grande into the Pailas River (Fig 1). The formation of the blockage was sufficiently quick to trap a group of river dolphins upstream of the blockage (F. Aguilera, pers. comm., 2011).

Following press coverage and public pressure, the Ministry of Environment and the General Directorate of Biodiversity decided to respond to this event, contacting the authors of this paper to investigate the situation and to find a possible solution to release the trapped dolphins. An immediate inspection of the area was scheduled, and a plan to relocate the animals was developed (Aliaga-Rossel and Escobar-WW, 2010).

\section{METHODS}

The trapped Bolivian bufeos were in a segment of the Pailas River (approximately at $16^{\circ} 18^{\prime} \mathrm{S}, 63^{\circ} 28^{\prime} \mathrm{W}$ ) located 6 to 8 hours drive from the city of Santa Cruz de la Sierra, Bolivia. The average annual temperature in this region is around $23^{\circ} \mathrm{C}$ and cold wind patterns called surazos can considerably lower the temperature during winter. The average annual rainfall is $950 \mathrm{~mm}$ and the hydrologic regime in the area is tightly linked to precipitation and displays a unimodal curve, the months of greatest rainfall are January and February and the lowest water levels occur from May to early November (Guyot, 1993).

\section{Surveys and river evaluation}

To have the authorisation of the local authority, information on water quality in the Pailas and Río Grande rivers was needed prior to the translocation of the bufeos. Therefore, water samples were taken following standard protocols and submitted to the accredited Laboratory of Environmental Quality of the University Mayor of San Andres in La Paz (Table 1).

The bufeos were trapped in a $3 \mathrm{~km}$ long river segment; but only about $1 \mathrm{~km}$ within this segment was of suitable depth for the animals. The average river width and depth were, respectively, $17 \mathrm{~m}$ and $2.5 \mathrm{~m}$, but at either end the water depth was less than $0.7 \mathrm{~m}$, muddy and covered with thick decomposing aquatic vegetation. As the dry season progressed, the water depth diminished and by the end of the rescue the river was completely dry upstream of the Seis Hermanos cattle ranch (Fig. 1).

Fishermen were interviewed during the first survey in the Pailas River to try to better understand how the river

\section{Table 1}

Water quality analysis of the Pailas and Río Grande Rivers. Samples taken the first day of the translocation.

\begin{tabular}{lccc}
\hline Parameter & Pailas River & Río Grande River & $\begin{array}{c}\text { Limit of } \\
\text { determination }\end{array}$ \\
\hline Suspended solids & $120-155$ & $588-705$ & 5 \\
Settleable solids & $<1.1$ & 1.9 & 1 \\
Total solids & $750-1,031$ & $1,360-1,430$ & 10 \\
BOD-5 & $23-28$ & $20-25$ & 0.2 \\
Nitrates & 1.7 & 0.22 & 0.3 \\
Free cyanide & $<0.0096$ & $<0.0096$ & 0.0096 \\
Total phosphorus & 0.34 & $<0.070$ & 0.07 \\
Fecal coliform & $90-230$ & 230 & 2 \\
Arsenic & $<0.0010$ & $<0.001$ & 0.001 \\
Cadmium & $<0.020$ & $<0.02$ & 0.02 \\
Mercury & $<0.0002$ & $<0.0002$ & 0.0002 \\
Lead & $<0.05$ & $<0.05$ & 0.05 \\
\hline
\end{tabular}


blockage and the trapping of the bufeos occurred. A list of mid-size fish, which included the bufeo's prey (AliagaRossel and McGuire, 2010), was developed on the basis of opportunistic captures with a fishing net, or by recording the identity of dead fish found on the shores on the Pailas River.

From May to August, ten surveys were conducted in the river from an outboard motorboat to assess the distribution of the bufeos. Surveys followed strip transect methods. The boat travelled along the centre of the river at a constant average speed of $7 \mathrm{~km}^{\mathrm{h}-1}$ with observer eye height of $2 \mathrm{~m}$ above water level $(n=10)$, with two observers plus a boat driver and additional people. The presence of bufeos was determined visually, or by listening for the noise of air exhalation and then by visual confirmation (Aliaga-Rossel, 2002). Each observer searched for the presence of dolphins at both sides of the boat, and to avoid duplication in the count there was a constant communication amongst them (AliagaRossel, 2002; Gomez-Salazar et al., 2012). Transects were surveyed during daytime and in periods of good visibility. Once detected, the number of bufeos and the time of day were recorded. As the length of the river was constant, the result presented was the number of bufeos per km. During each survey the depth of the river was recorded, and a slow decrease in the water depth during the course of the surveys was detected. Also, the research team searched for mortality events or indicators of possibly declining health of the bufeos (e.g. wounds to the skin). As a result of these surveys, it was determined (in July) that the bufeos needed to be translocated to the main river (the Río Grande) or they would perish because of the reduced water levels, poor water quality and insufficient food supply. At this time, the translocation plan was initialised.

\section{Translocation areas}

After a general evaluation of the Río Grande, the absence of bufeos several kilometres upriver from the blockage and the presence of the species downriver were deemed as the first criteria to define possible release sites. Three areas were selected for translocation in the main Río Grande River. The first was Puerto Piraña (Piranha Port), a region approximately $20 \mathrm{~km}$ downstream from the blockage, past a series of three rapids. This location was considered as most favourable because of the relatively low water flow and an average depth of $4 \mathrm{~m}$. In addition, local inhabitants confirmed that bufeos were regularly present in the area, suggesting it constituted a suitable habitat for the animals. The second area was Santa Rita, $10 \mathrm{~km}$ downstream from the blockage. The third area was closer (less than $1 \mathrm{~km}$ from the blockage). Both these latter areas had similar characteristics to Puerto Piraña. Information on group composition was to be considered prior to the release of the bufeos (e.g. animals captured together were to be released together) as release was to be conducted across the three different sites to minimise possible food competition (Aliaga-Rossel, 2002; Trujillo et al., 2011).

\section{Capture, transport and release}

Captures were undertaken following a handling protocol established in advance. Two to four experienced fishermen set one or two $30 \mathrm{~m}$ by $6 \mathrm{~m}$ cotton fishing nets. These nets were specially constructed loosely to reduce any possible harm to the bufeos during capture. The rescuers started searching for bufeo and then released the nets. The ends of the nets were gradually moved towards each other, reducing the area available, to finally trap the dolphins. Once an animal was trapped, it was immediately lifted to the surface, carefully maintaining its blowhole out of the water, and carried to be placed in a stretcher for transport. The bufeo was then transported to a landing site built by the rescue team called 'Port B' and located in the middle section of the Pailas River (Fig. 1). A small fenced off area made of plastic $1 \mathrm{~mm}$ mesh and metal pipes was built in the river in case a newborn or young bufeo needed to be temporarily confined while the mother was captured. If the mother was not captured quickly, the young individual would be released back into the river. Once a captured bufeo arrived at Port B it was placed on van or a truck. These vehicles were equipped with thick foam mattresses and sheets tied up to the roof to protect the bufeo from direct sun and dust during transportation. An improvised dirt road was built by the team and the vehicle travelled 20 to 25 minutes at speeds of 10 to $15 \mathrm{~km}^{\mathrm{h}-1}$ towards the blocked mouth of the Pailas River adjacent to the Río Grande. The bufeos were then carried to inflatable boats specially fitted for the transportation of the animals to any of the release areas. The boat trip lasted from one to three hours depending on the selected site. Two or three volunteer biologists accompanied the bufeos at all times, monitoring their general health and comfort, and treating any scratches with a topical antiseptic (gentian violet). Their body was kept moist with wet sheets. Respiratory frequency was also monitored, and the position of the bufeos was changed during transit if necessary.

To release the bufeos, the head and the blowhole were kept out of the water while the body was slowly introduced to the water. The released animals were followed from the shore for two hours. To evaluate their general state after release, they were relocated two days later.

\section{RESULTS}

\section{Surveys and river evaluation}

Interviews with several fishermen undertaken during the first survey all indicated that the blockage was caused by sediments washed down by unusually fast flooding against an embankment which had been built at the entrance of the Pailas River. They highlighted that the blockage made fish capture easy. Fishermen expressed the opinion that bufeos would compete for fish resources and that they would be willing to kill them to remove this competition. Uncontrolled hunting and fishing are common in the region and, as a result, up to $70 \%$ more fish than allowed are captured (H. Martinec, pers. comm., 2012). Once the bufeos were confirmed as trapped, the Government of Santa Cruz ordered a ban on hunting and fishing in the entire Río Grande area. This ban and the higher control of the region by local authorities during the translocation, kept fishermen away from the river temporarily. A quick evaluation of the fish available in the Pailas River resulted in the identification of 18 fish species from at least seven families. The greatest proportions of these fish were in the family Characidae, which are non-commercial fishing species, however commercial species such as Pacu (Colossoma macroponum) and Surubi (Pseudoplatystoma trigrinum) were also found. 
The water quality analysis revealed medium levels of Escherichia coli (Table 1). High levels of decomposing organic matter were detected in the water, and dead fish and rotten vegetation was seen on the shoreline.

\section{Capture and translocation}

Using a strip line transect method ( $n=10$ surveys), the estimated number of river dolphins trapped ranged from 10 to 16 (mean $=12.4, \mathrm{SE}=0.73$ bufeos $)$ including 3 calves and 2 juveniles (encounter rate $=12.4$ bufeos $\mathrm{km}^{-1}$ ).

The first two bufeos presented strong resistance to capture attempts and captures became even more complicated over time. The bufeos learned to avoid the nets by spending more time submerged, finding gaps or holes in the net or staying close to the river's bottom, hiding in areas with abundant aquatic vegetation or surfacing very subtly while breathing quietly. One male jumped over the net to escape from being captured.

A total of 26 individuals were captured and released (Table 2) over a period of 13 days in August 2010. Besides the handling stress and a few scratches from the capture, none of the bufeos showed major signs of harm. None showed visible skin lesions or infections due to temporarily inhabiting stagnant water. During the release, all animals reacted as soon they felt resumed contact with water; they struggled and slashed their tails to move away and rapidly swam into the river.

Three calves (one likely younger than one month) and four juveniles were released close to their mothers. All were in good condition. After release, one of the females with a newborn calf was also seen in close company of a juvenile,

Table 2

Measurements $(\mathrm{cm})$ of the translocated Bolivian river dolphins to the Río Grande River from the Pailas River, Santa Cruz, Bolivia.

\begin{tabular}{cccccccc}
\hline N & Sex & TL & LTJMO & LLJ & LPF & WPF & WF \\
\hline 1 & Juvenile F & 155 & 16 & - & 36 & - & 36 \\
2 & Juvenile M & 151 & 22 & - & 31 & 14 & 37 \\
3 & F & 170 & 20 & 21 & 43 & 17 & 41 \\
4 & F & 240 & 30 & 27 & 49 & 23 & - \\
5 & F & 212 & 25 & 23 & 46 & 17.5 & 45 \\
6 & F & 220 & 35 & - & 41 & 22 & - \\
7 & Calf M & 117 & 23 & - & 23 & - & 25 \\
8 & M & 155 & - & - & 30 & 14 & 25 \\
9 & M & 192 & - & 26 & 37 & 16 & 41 \\
10 & M & 235.5 & 32 & 40 & 47 & 20.5 & 53 \\
11 & M? & 143.5 & 13.5 & 19.5 & 28.5 & 13.5 & 21.5 \\
12 & M & 154 & 12 & 20.5 & 29 & 14 & 32.5 \\
13 & F & 236.5 & 25 & 33.5 & 35 & 20.5 & 52 \\
14 & $?$ & 192 & 26 & 30 & 49 & 17.5 & 46 \\
15 & F & 194 & 25 & 34 & 43 & 18 & 47 \\
16 & F & 232 & 33 & 25 & 44 & 15 & - \\
17 & M & 230 & 32 & 40 & 46.5 & 21 & \\
18 & Pregnant F & 218 & 23 & 20 & 47 & 16 & 47 \\
19 & Lactating F & 210 & 27 & 25 & 45 & 23 & 48 \\
20 & Juvenile F & 190 & 40 & - & 45 & 19 & 47 \\
21 & Juvenile ? & 110 & 8 & 8 & 23 & 10 & 25 \\
22 & F & 236 & 34 & 33 & 51 & 20 & 51 \\
23 & F & 210 & 29 & 29 & 51 & 19 & 50 \\
24 & F & 239 & 37 & 27 & 52 & 21 & 55 \\
25 & F & 233 & 24 & 23 & 43 & 19 & 51 \\
26 & M & 235 & 26 & 24 & 47 & 20 & 50 \\
\hline & & & & & & & \\
\hline
\end{tabular}

Key: $\mathrm{F}=$ female; $\mathrm{M}=$ male; $?=$ unknown sex. $\mathrm{TL}=$ total length; $\mathrm{LTJMO}=$ length from the tip of the upper jaw to mouth basis; LLJ = length lower jaw; LPF $=$ length pectoral fin; WPF $=$ width pectoral fin; WF $=$ width of fluke. probably her offspring from a previous year. These three individuals were seen swimming together for several hours. At times the juvenile moved away by a few meters but then returned close to the female.

Three females were possibly pregnant, based on the size of the abdomen, including the largest bufeo captured $(243 \mathrm{~cm}$ total length). A remarkably large $(235 \mathrm{~cm})$ male had an amputated left pectoral fin. The scar was completely healed, suggesting that the limb was lost at a younger age.

\section{DISCUSSION}

\section{Capture and translocation}

To our knowledge, this was the first time the rescue and translocation of a large number of river dolphins has been documented. When the bufeos were first trapped in the Pailas River, the dry season had started (May) and the water levels in the river were rapidly dropping. The authors waited for two months with continuous monitoring to assess whether translocation was needed, but potential threats to the animals were increasing, including deterioration of the water quality which could risk the bufeos' health via skin irritations and other diseases (Van Bressem et al., 2009). There was also a risk of starvation due to possible food shortage and intra and interspecific competition for prey, as well as the risk that the water levels would drop so low that the dolphins would become stranded and die. The number of available fish species was not quantified, just a qualitative evaluation was performed. Fish of the Characidae family, found in relatively high proportion, was previously reported as an important prey item in the diet of juvenile Bolivian bufeo (AliagaRossel et al., 2010). In addition, fish of this family were also important among 43 fish species of 19 families found in the diet of the Amazon river dolphins (I. geoffrensis) in Brazil (Best and da Silva, 1993).

The unusual weather conditions in the area (frequent heavy rains and low temperature), slowed down the water level drop, allowing enough time to monitor the trapped bufeos, and to organise and prepare for their capture and translocation. Several possibilities to avoid handling the animals were evaluated; including re-opening of the channel with heavy machinery. However, this was deemed unfeasible because the blockage was extensive and the relatively large and boggy conditions of terrain were not suitable for the operation of heavy machinery.

The bufeos were released separately depending on when the captures occurred, except for mothers and calves which were always released together. Therefore, each group released was not necessarily related in the conventional definition of a group and the release of individuals together did not imply social cohesion (Aliaga-Rossel, 2002). During the next rainy season it was probable that groups released in the three separate locations would have reunited because the average depth of the river increased at that time by at least $2 \mathrm{~m}$, allowing animals to swim past shallower areas and to move across the rapids separating the three sites.

Prior to being trapped, the bufeos may have been either full time residents in the Pailas River or have used it seasonally. In other areas, females are known to prefer areas with low river flow, which can be a suitable habitat for newborns and calves (Trujillo et al., 2011). Therefore, the 
calm water conditions in the Pailas River may explain the large number of bufeos present, especially the pregnant females and calves.

Initial estimations predicted that there were $12-16$ bufeos present but the final number captured was 26 individuals including a calf with a mother and two calves thought to have been born during the period of the surveys. This was a good opportunity to evaluate the accuracy of density and abundance estimations, by removing and counting the actual number of dolphins and comparing these numbers with the surveys. The observers were experienced in working with bufeos and using standardised methods with replicates on a population inside a fixed area, however the difference between the estimated number of bufeos to the actual number of dolphins captured was at a level of nearly $40 \%$, suggesting that our surveys (and possibly published studies conducted with the same method) may be underestimating the real numbers of bufeo, an underestimate which could increase if inexperienced observers are used during the search. However, it is also possible that the constant presence of fishing boats and other activities in the area had driven the bufeos to be harder to find, tending to hide in the presence of humans, as observed during their capture. This behaviour would lead to a smaller proportion of animals detected in the strip transect surveys in this case than possibly in other more typical survey conditions.

During this rescue, three interesting anecdotal or circumstantial observations were documented: (1) the rapid learning curve to avoid the nets and boats; (2) an adult female swimming in close proximity with a newborn and a juvenile (perhaps an older calf or an animal that separated from its mother and joined the mother-calf pair); and (3) a female making physical contact through the net with a one year-old calf (possibly her calf) that had been captured and kept inside the net pool. This female stayed in the same area as the calf until it was captured without resistance and reunited with the younger individual. There are limited behaviour studies on this species and the significance of these anecdotal reports should be investigated further.

It is also important to highlight the capture of a male with a missing fin and a scar with the configuration and shape indicative of mutilation caused by fishing gear (versus a predator). Despite its injury, this dolphin appeared to be in good health. This individual was again rescued six years later from an irrigation channel $20 \mathrm{~km}$ away which was less than $1 \mathrm{~m}$ deep. The dolphin was moved again to the Río Grande. In recent years the number of stranded dolphins in the entire area has increased (W.A. Montaño, pers. comm., 2019).

The temporary ban on fishing and hunting ended when the translocation of the dolphins was complete. The fisherman and alligator hunters returned to the Río Grande area, where fishing nets are still left unattended and the shooting of bufeos continues to the present day. These are ongoing threats to the local river dolphin population.

\section{River and water quality}

The lower basin of the Río Grande is the most degraded area of the river dolphins' habitat in Bolivia. There, several threats to this species have been documented, including high levels of deforestation, water pollution and overfishing (F. Aguilera, pers. comm., 2014). The habitat requirements of the bufeo has restricted them to areas with increased human activity and population. During the time of the rescue an unusually high fish die off occurred in the entire sub basin. This was attributed to unseasonably low temperatures. Thousands of fish, alligators and turtle carcasses covered rivers and channels for several kilometres. The decomposition of these carcasses decreased water quality rapidly, including the area where the dolphins were trapped, and precipitated the decision to move the dolphins.

Although the results from the water samples suggested that bacteria (e.g. E. coli) and organic matter levels were within normal to high limits, there were high concentrations of total solids but few precipitates. Most solids were in suspension (as a colloid), consistent with the characteristics of tropical rivers (water exposed) such as the Río Grande. The organic matter contained in the water was evaluated using the BOD-5 method, which assesses oxygen consumed by microorganisms over five days in laboratory conditions, the values were high. As expected, heavy metals were not present, or the presence of herbicides or pesticides in the water could not be evaluated. Phosphorus levels were high in the Pailas River. Even though the analysis indicated that the water was not as yet at toxic levels, the number of bacteria present in the river was a strong indication of sewage or animal waste contamination. Cattle ranches on the shores, the sewage output from agricultural companies, fish, and the elevated number of river dolphins trapped in that small segment may have contributed to the high faecal coliform levels (Hansen et al., 2008; Ishii et al., 2007; Ishii and Sadowsky, 2008; Vinten et al., 2004). Pollution levels in Bolivian rivers are still low and are not extreme as the other river dolphin habitats such as the Ganges where uncontrolled pollution (including sewage, industrial effluents, runoff of chemical fertilisers and pesticides) have also contributed to the decline of Ganges river dolphin populations (Choudhury et al., 2010; Reeves and Gales, 2006).

\section{Landscape modifications and habitat degradation}

Habitat degradation in the Río Grande area is a consequence of several factors that adversely affect the environment. The entire area belongs to large private agricultural companies and has been transformed into intensive agriculture land, following illegal and uncontrolled deforestation. This transition has reduced the ties of the populace to the land and wildlife. Local indigenous communities no longer live in the area and there are no clear laws or regulations to manage land use. Logging is widespread and most of the region has been modified through deforestation. Waterways, small tributaries and other water bodies have been transformed into irrigation channels to water the extensive crop plantation. There is limited management of agricultural chemicals and residues. For example, agrochemical containers are often dumped into water channels. Illegally built dirt roads often block small streams. All these activities have contributed to reducing the annual cycle of water flow, affecting the hydrology of the rivers and interrupting the flow of sediments. 
The blockage of the Pailas River resulted from the cumulative negative effects of landscape modification over time. Small changes in this landscape can have far-reaching consequences. For example, in the early 2000s, a farmer decided to change the course of some streams to make navigation quicker within a complex of interconnected Río Grande lagoons, including Pistol Lagoon. This simple action drained part of the latter, turning the lagoon into a swamp (F. Aguilera, pers. comm., 2013). Because the bufeos use these lagoons seasonally (Aliaga-Rossel, 2010), changes in the river network can have a detrimental effect on some of their important habitats.

In December 2010, during the final evaluation on the translocated bufeos, the Pailas River had turned into a swampy area and, despite the start of the rainy season when the river was expected to be flooding, the river almost dried up. Currently the Pailas River remains dry and some agricultural areas have extended into the former channel. Deforestation and habitat degradation have increased in vast areas of Santa Cruz. Local authorities indicate that changes in the landscape are frequent, but lack of communication with the national government, confusing and contradictory laws, and the new National policy to aggressively expand the agricultural frontier, is leading to the replacement of thousands of hectares of forest with agricultural land.

Habitat conservation for river dolphins is especially challenging (Reeves et al., 2000). Habitat degradation is a significant conservation problem for these species because of their endemic nature and relatively limited distribution. This has contributed to the extinction of the Baiji in China (Wang, 2006; Smith and Reeves, 2012) and to the decline of the Ganges and Indus river dolphins in southern Asia (Kreb et al., 2010; Reeves et al., 2000) and of the Amazon river dolphin (Inia geoffrensis) in South America (da Silva et al., 2018). If proper conservation efforts are not established, deforestation and modification of the habitat will continue to impact the poorly known and highly endemic Bolivian river dolphin. Events where river dolphins become trapped in South America may happen even more frequently than anticipated, possibly not always being fully documented or reported especially when they occur in remote regions. Therefore, it is important to continue with research to assess the status of populations of Inia and to generate public awareness to highlight threats to the survival of these species. The numbers of researchers studying river dolphins in South America is slowly increasing, and the resulting opportunities for collaboration and interchange of experiences will improve conservation efforts. It is important for the future, to consolidate a network of local stakeholders, including researchers, local authorities and decision makers to ensure the long-term survival of the endangered river dolphins in the Amazon.

\section{ACKNOWLEDGEMENTS}

Thanks for the support of Gas Trans Boliviano (GTB), Whale and Dolphin Conservation (WDC), World Wildlife Fund (WWF), Fundación estás Vivo, Omacha Foundation, Foundation SAR (Funsar), people from Seis Hermanos cattle ranch. Special thanks to Ismar Freyre, who alerted us about the bufeos and helped with the capture. Thanks also to V. da
Silva (INPA), M. Ruiz-García (Universidad Javeriana), F. Trujillo (Omacha), T. McGuire (LGL Alaska Research Associates), A. Wood (WDC), M. Marmotel (INPA), E. Boede (Deceased 2019; Acuario Valencia-Venezuela), R. Wallace and L. Painter (WCS-Bolivia), L. Saenz and S. Usma (WWF), V. Albarracin, A. Costidis, L. Barret, A. Irvine for their interest, comments, suggestions and collaboration. J. Sarmiento helped with fish identification. Thanks to R. Callau and the Funsar volunteers. Thanks to the volunteers that helped with translocation: R. Alba, O. Callaú, Z. Chavez, L. Guizada, W.A. Montaño, R. Alarcon, F. Aguanta, N., RC Paca, N. Rocha, L. Ortega, M. Amaya, D. Ramos, O. Helming, J. Pinto, M. Castro, B. Manu and H. Montecinos. Thanks to the Santa Cruz Governor R. Costas, and M. Roca, F. Aguilera, H. Martinec, W. Titze from the Government of Santa Cruz. Thanks also to the General Directorate of Biodiversity and all the team that facilitated the actions of all the rescue/translocation team. This manuscript was greatly improved thanks to A. Rudd (Hawai'i Institute of Marine Biology), and A. Zerbini. Thank you also to the anonymous reviewers for their comments and suggestions.

\section{REFERENCES}

Aguirre, L., Aguayo, R. and Balderrama, J. 2009. Libro Rojo de la Fauna Silvestre de Vertebrados de Bolivia [The Red Book of Vertebrates in Bolivia]. Ministerio de Medio Ambiente y Agua, La Paz, Bolivia. 776pp. Aliaga-Rossel, E. 2002. Distribution and abundance of the river dolphin (Inia geoffrensis) in the Tijamuchu River, Beni, Bolivia. Aquatic Mammals 28(3): 312-23.

Aliaga-Rossel, E. 2010. Conservation of the river dolphin (Inia boliviensis) in Bolivia. pp.55-70. In: Ruiz-Garcia, M. and Shostell, J. (eds). Biology, Evolution and Conservation of the River dolphins in South America and Asia. Nova Publishers, New York, USA. 504pp.

Aliaga-Rossel, E., Beerman, A. and Sarmiento, J. 2010. Stomach content of a juvenile Bolivian River dolphin (Inia geoffrensis boliviensis) from the Upper Madeira Basin, Bolivia. Aquatic Mammals 36: 284-87.

Aliaga-Rossel, E. and Escobar-WW, M. 2010. General plan and protocol for the handling and translocation of the Bufeos (Inia boliviensis) trapped in the Pailas River - Bolivia. Technical Report for the Ministry Environmental and Water and the General Direction of Biodiversity, La Paz, Bolivia. 10pp.

Aliaga-Rossel, E. and McGuire, T.L. 2010. Iniidae. pp.535-70. In: Wallace, R.B., Gómez, H., Porcel, Z.R. and Rumiz, D.I. (eds). Distribución, Ecología y Conservación de los Mamíferos Medianos y Grandes de Bolivia. Editorial: Centro de Ecología Difusión Simón I. Patiño, Santa Cruz, Bolivia. [In Spanish]. 880pp.

Best, R.C. and da Silva, V.M.F. 1993. Inia geoffrensis. Mammalian Species 426: $1-8$.

Choudhury, B.C., Behera, S. and Wakid, A. 2010. A review of the conservation status and protected areas for the Susu Platanista gangetica gangetica, Bhulan Platanista gangetica minor and Irrawaddy dolphin Orcaella brevirostris in the Ganges, Brahmaputra and Beas Rivers, and Chilika Lagoon, India. In: Kreb, D., Reeves, R.R., Thomas, P.O., Braulik, G.T. and Smith, B.D. (eds). Establishing Protected Areas for Asian Freshwater Cetaceans - Freshwater Cetaceans as Flagship Species for Integrated River Conservation Management. Yayasan Konservasi RASI/Conservation Foundation for Rare Aquatic Species of Indonesia. 166pp.

Choudhury, S., Dey, S., Dey, S., Sagar, V., Nair, T. and Kelkar, N. 2012. River dolphin distribution in regulated river systems: implications for dry-season flow regimes in the Gangetic basin. Aquat. Conserv. 22: 1125 .

da Silva, V., Trujillo, F., Martin, A., Zerbini, A.N., Crespo, E., Aliaga-Rosel, E. and Reeves, R. 2018. Inia geoffrensis. 2008 IUCN Red List of Threatened Species, Version 2014.3. [Available from: www.iucnredlist.org]. Gomez-Salazar, C., Trujillo, F., Portocarrero-Aya, M. and Whitehead, H. 2012. Population, density estimates, and conservation of river dolphins (Inia and Sotalia) in the Amazon and Orinoco river basins. Marine Mammal Science 281: 124-53.

Gravena, W., Farias, I.P., da Silva, M.N.F., da Silva, V.M.F. and Hrbek, T. 2014. Looking into the past and the future: were the Madeira River rapids a biological barrier to the boto (Cetacea: Iniidea)? Conservation Genetics 15: 619-29. 
Guyot, J.L. 1993. Hydrogéochimie des Fleuves de l'amazonie Bolivinne. ORSTOM, Paris, France. 261pp.

Hansen, D.L., Clark, J.J., Ishii, S., Sadowsky, M.J. and Hicks, R.E. 2008 Sources and sinks of Escherichia coli in benthic and pelagic fish. J. Great Lakes Res. 34: 228-34.

Ishii, S., Hansen, D.L., Hicks, R.E. and Sadowsky, M.J. 2007. Beach sand and sediments are temporal sinks and sources of Escherichia coli in Lake Superior. Environ. Sci. Technol. 41: 2203-09.

Ishii, S. and Sadowsky, M.J. 2008. Escherichia coli in the environment: Implications for water quality and human health. Microbes Environ. 23: 101-08.

IUCN. 2012. Guidelines for Reintroductions and Other Conservation Translocations. IUCN Species Survival Commission. Adopted by SSC Steering Committee at 5th Meeting SC $46.18 \mathrm{pp}$.

Kelkar, N., Krishnaswamy, J., Choudhary, S. and Sutaria, D. 2010. Coexistence of fisheries with river dolphin conservation. Conservation Biology 24: 1130-40.

Kreb, D., Reeves, R.R., Thomas, P.O., Braulik, G.T. and Smith, B.D. 2010 Establishing protected areas for Asian freshwater cetaceans: Freshwater cetaceans as flagship species for integrated river conservation management. Final Workshop Report. Yayasan Konservasi RASI, Samarinda, Indonesia. 166pp.

Reeves, R.R. and Gales, N. 2006. Realities of baiji conservation. Conservation Biology 20: 626-28.

Reeves, R.R., Smith, B.D. and Kasuya, T. 2000. Biology and conservation of freshwater cetaceans in Asia. Occasional paper of the IUCN Species Survival Commission No.23. IUCN, Gland, Switzerland. 153pp

Ruiz-Garcia, M., Caballero, S., Martinez-Aguero, M. and Shostell, J.M. 2008. Molecular differentiation among Inia geoffrensis and Inia boliviensis (Iniidae, Cetacea) by means of nuclear intron sequences. pp.177-203. In: Koven, V.T. (eds). Population Genetics Research Progress. Commack, NY, Nova Publishers Inc., Boca Raton, FL, USA. 340pp.
Smith, B.D. and Reeves, R.R. 2012. River cetaceans and habitat change: generalist resilience or specialist vulnerability? Journal of Marine Biology 2012(Article ID 718935): 11pp.

Smith, B.D., Zhou, K., Wang, D., Reeves, R.R., Barlow, J., Taylor, B.L. and Pitman, R. 2008. Lipotes vexillifer. IUCN Red List of Threatened Species. Version 2012.2. International Union for Conservation of Nature. [Accessed 2 January 2015].

Trujillo, F., Crespo, E., Van Damme, P.A. and Usma, J.S. 2010. The Action Plan for South American River Dolphins 2010-2020. WWF, Fundacion Omacha, WDS, WDCS. Solamac. Bogota, D.C., Colombia. 249pp.

Trujillo, F., Diazgranados, M.C., Utreras, V., Aliaga-Rossel, E. and Rodríguez-Maldonado, M.V. 2011. River dolphins in South America [Delfines de río en Suramérica]. Fundación Omacha, Serie de Especies Amenazadas No. 2, Bogotá, Colombia. 64pp.

Turvey, S., Pitman, R.L., Taylor, B., Akamatsu, T., Barrett, L.A., Zhao, X. Reeves, R., Stewart, B., Wang, K.R., Wei, Z., Zhang, X., Richlen, M., Brandon, J. and Wang, D. 2007. First human-caused extinction of a cetacean species? Biol. Lett. 3: 537-40.

Van Bressem, M.F., Santos, M.C. and de O. Oshima, J.E.F. 2009. Skin diseases in Guiana dolphins (Sotalia guianensis) from the Paranaguá estuary, Brazil: a possible indicator of a compromised marine environment. Mar Environ Res 67: 63-68.

Vinten, A.J.A., Douglas, J.T., Lewis, D.R., Aitken, M.N. and Fenlon, D.R. 2004. Relative risk of surface water pollution by $E$. coli derived from faeces of grazing animals compared to slurry application. Soil Use Management 20: 13-22.

Wakid, A. and Braulik, G. 2009. Protection of endangered Ganges river dolphin in Brahmaputra River, Assam, India. Final Technical Report to Sir Peter Scott Fund, IUCN. 44pp.

Wang, D., Zhang, X., Wang, K., Wei, Z., Wursig, B., Braulik, G. and Ellis, S. 2006. Conservation of the baiji: No simple solution. Conserv. Biol. 20:623-25. 